\title{
THE RELATIONSHIP BETWEEN PLASMA PROGESTERONE CONCENTRATION AND CONCEPTION IN POST-PARTUM DAIRY COWS MAINTAINED ON TWO LEVELS OF NUTRITION*
}

\author{
Y. FOLMAN, MIRIAM ROSENBERG, Z. HERZ AND M. DAVIDSON $\dagger$ \\ Agricultural Research Organization, The Volcani Center, \\ Bet Dagan, Israel
}

(Received 3rd Fuly 1972)

\begin{abstract}
Summary. Fourteen dairy cows were maintained on high and standard (low) levels of nutrition. Plasma progesterone concentration was determined by a protein-binding method every 4 days from 10 days post partum until pregnancy. Cows that conceived after one insemination had significantly higher progesterone levels during the oestrous cycle preceding insemination than did cows that did not conceive. Correlation coefficients between the occurrence of conception after the first insemination and plasma progesterone concentration during the preceding luteal phase were statistically significant. Cows maintained on a high level of nutrition required fewer inseminations per conception, conceived earlier and had a high plasma progesterone level 23 days earlier than cows maintained on a standard level of nutrition. In cows that conceived after one insemination, level of nutrition had no effect on progesterone concentration but it had a profound effect in cows that needed more inseminations for conception. During the luteal phase preceding insemination, cows that conceived after the first insemination gained weight whereas cows that did not conceive lost weight; the difference approached significance. The correlation coefficient between body weight changes and progesterone concentration 8 to 15 days before the first insemination approached significance $(r=0.492)$. It is suggested that plasma progesterone concentration during the oestrous cycle preceding insemination is closely related to the occurrence of conception.
\end{abstract}

\section{INTRODUCTION}

The concentration of progesterone in the peripheral plasma of the post-partum cow, at various stages of the oestrous cycle, has been determined by many workers (Schomberg, Coudert \& Short, 1967; Pope, Gupta \& Munro, 1969; Stabenfeldt, Ewing \& McDonald, 1969; Donaldson, Bassett \& Thorburn, 1970;

* Contribution from the Volcani Genter, Bet Dagan, Israel. Serial No. 2146-E.

$\dagger$ Hahaklait, Rishon Le-Zion. 
Henricks, Dickey \& Niswender, 1970; Hill, Lamond, Henricks, Dickey \& Niswender, 1970; Erb, Surve, Callahan, Randel \& Garverick, 1971; Garverick, Erb, Niswender \& Callahan, 1971; Shemesh, Lindner \& Ayalon, 1971; Snook, Saatman \& Hansel, 1971; Sprague, Hopwood, Niswender \& Wiltbank, 1971).

Attempts were also made to correlate steroid concentration in blood and urine to the incidence of delayed conception and reduced fertility in clinically healthy cows. Most workers who tried to relate progesterone concentration in plasma or serum to the incidence of conception, however, concentrated their efforts on the period after insemination or mating (Shemesh, Ayalon \& Lindner, 1968; Henricks, Lamond, Hill \& Dickey, 1971; Randel, Garverick, Surve, Erb \& Callahan, 1971).

Erb, Randel \& Callahan (1971) tried to relate abnormal post-partum reproductive function to plasma progesterone concentration before insemination. They concluded that there was no evidence that progesterone levels were different in post-partum abnormal and normal cows. Henricks et al. (1971) found an inverse relationship in beef heifers between plasma progesterone concentration during the 2-day period before oestrus and the number of blastomeres in the blastocyst 3 days after mating. The authors suggested that high progesterone levels before oestrus could reduce fertility.

Following parturition, uterine involution and post-partum quiescence, profound changes have to occur in the reproductive tract of the female before conception can take place (Wagner \& Oxenreider, 1971). As progesterone is known to have various effects on the female reproductive tract (Miyake, 1962), it was the purpose of this study to determine whether conception is in any way related to plasma progesterone concentration before insemination.

\section{MATERIALS AND METHODS}

\section{Animals}

Fourteen Israeli-Friesian dairy cows were allocated after parturition to two treatments. Eight cows were individually fed a high-energy ration consisting of $6 \mathrm{~kg}$ hay and had free access to concentrates. Six cows were individually fed a standard ration consisting of $6 \mathrm{~kg}$ hay and concentrates for production. The maintenance requirement was assumed to be $4.0 \mathrm{f}$.u. (Scandinavian feed units) for $500 \mathrm{~kg}$ body weight and $0 \cdot 1 \mathrm{f}$.u. extra for every $20 \mathrm{~kg}$ over 500 . For production, 0.4 f.u. $/ \mathrm{kg}$ of $4 \%$ fat-corrected milk yield was fed. Two $\mathrm{kg}$ hay were estimated to provide 1 f.u.

All cows were milked three times daily and weighed twice weekly. Milk yield was recorded daily. The state of the ovaries and uterus was determined by rectal palpation twice weekly. First service by artificial insemination was delayed a minimum of 56 days post partum. The cows were inseminated on the day of oestrus and again on the following day. Cows which did not return to service by 45 days after insemination were examined for pregnancy at that time. Cows that were found to be pregnant were regarded as having conceived at the previous insemination.

Blood $(70 \mathrm{ml})$ was collected from a jugular vein every 4th day at about 10.00 hours and kept on ice till centrifugation. Collection was carried out from 
10 days post partum until the cow was found to be pregnant. The plasma was stored at $-18^{\circ} \mathrm{C}$ until used for progesterone determinations.

\section{Progesterone determination}

Progesterone was determined in 0.5 to $1.0 \mathrm{ml}$ plasma by the protein-binding method described by Edqvist, Ekman, Gustafsson \& Aström (1970) with the following modifications. (a) The plasma samples were extracted first with 10 and then with 5 vols of petroleum ether. The combined extracts were evaporated to dryness in a water bath at $55^{\circ} \mathrm{C}$. The efficiency of extraction was determined by adding a known amount of $\left[{ }^{14} \mathrm{C}\right]$ progesterone to $1 \mathrm{ml}$ plasma which was then extracted. It was found to be $101 \pm 7 \%$ (mean \pm S.D.). (b) The proteinbinding solution $\left(\mathrm{CBG}-\mathrm{B}^{3} \mathrm{H}\right)$ was prepared by binding $\left[1,2-{ }^{3} \mathrm{H}\right]$ corticosterone to the corticosteroid-binding globulin present in $2 \%$ male chicken plasma which had been kept at $-18^{\circ} \mathrm{C}$ until required. The CBG-B ${ }^{3} \mathrm{H}$ solution was prepared $16 \mathrm{hr}$ before the beginning of the assay and kept at $0^{\circ} \mathrm{C}$ until needed.

The precision of the method was determined by calculating the error of estimation from duplicate plasma samples according to the formula $\mathrm{S}=$ $\left(\Sigma \mathrm{d}^{2} / 2 n\right)^{\frac{1}{2}}(\mathrm{~d}=$ difference between duplicate values, $n=$ number of duplicate pairs). In the present experiment, $\mathrm{S}=0.57 \mathrm{ng} / \mathrm{ml}(n=65)$.

The accuracy of the method was determined by adding known amounts of crystalline progesterone to plasma collected from a cow on the day of oestrus. The mean recovery of the added progesterone, in the range of 0.5 to $3.0 \mathrm{ng}$, was found to be $105 \pm 15 \%$.

For statistical evaluation of the results, Student's $t$ test and analysis of variance, followed by Duncan's multiple range test, were used. Simple (Pearson's) and point biserial correlation coefficients were also calculated.

\section{RESULTS}

\section{Progesterone concentration and conception}

The plasma progesterone concentration of cows that conceived after the first insemination was significantly higher, 4 to 15 days before oestrus, than that of cows that did not conceive (Text-fig. 1). Among the eight cows that conceived, only one had less progesterone than $5 \mathrm{ng} / \mathrm{ml}$ plasma 4 to 7 days before insemination. Among those that did not conceive, only one had a progesterone level above $5 \mathrm{ng} / \mathrm{ml}$ plasma.

Point biserial correlation coefficients between the occurrence of conception after the first insemination and plasma progesterone concentration on Days 4 to 7,8 to 11 and 12 to 15 preceding this insemination were $r=0.70,0.62$ and 0.58 , respectively. The coefficients were statistically significant: $P \leqslant 0.01,0.02$ and 0.05 , respectively. Correlation coefficients between the occurrence of conception and plasma progesterone concentration on other days of the oestrous cycle were low and statistically not significant.

During the 16 days following the first insemination, plasma progesterone levels of cows that conceived did not differ significantly from those of cows that did not conceive. Cows that did not conceive after the first insemination and were consequently inseminated after longer intervals post partum had lower 


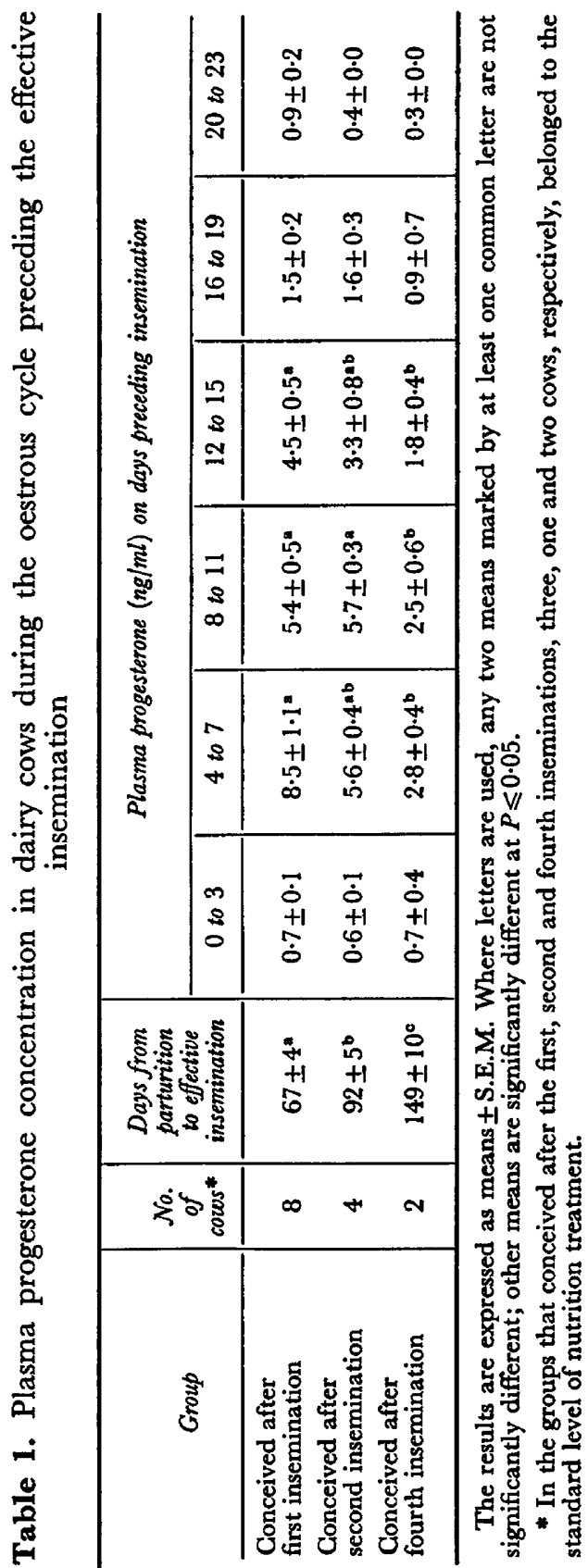


progesterone concentrations during the luteal phase of the cycle preceding the effective insemination than did cows that conceived after the first insemination (Table 1).

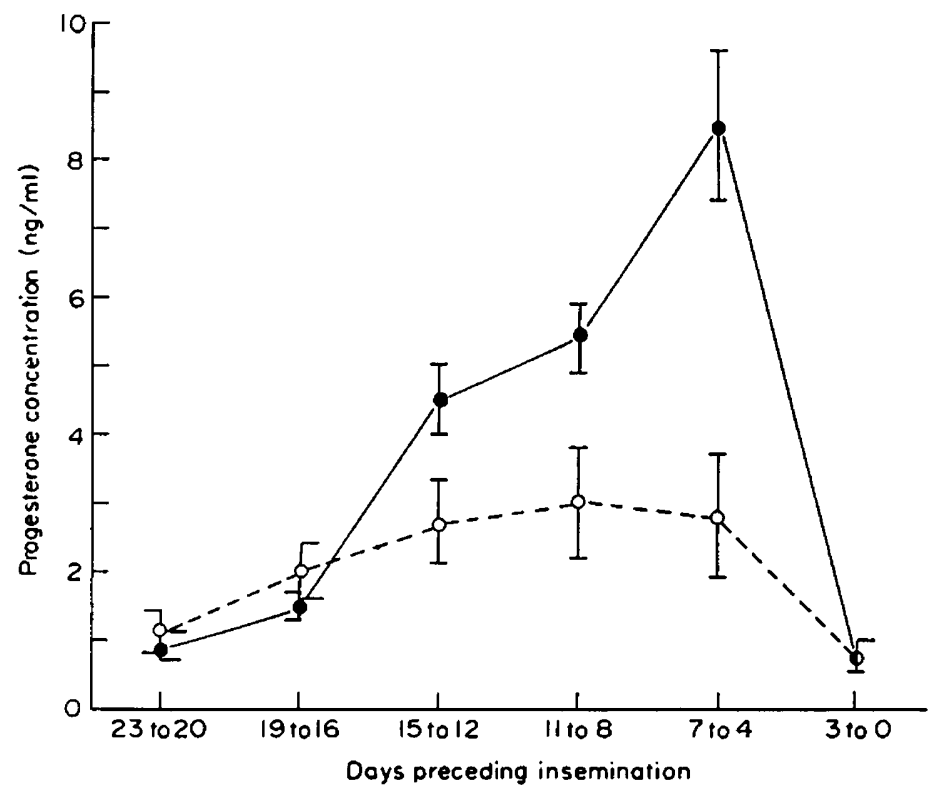

TExT-FIG. 1. Mean progesterone concentrations in dairy cows during the oestrous cycle preceding the first insemination. $\bullet$, Cows (eight) that conceived after the first insemination; $O$, cows (six) that did not conceive after the first insemination. Vertical bars represent \pm S.E. Differences between progesterone levels 15 to 12 and 11 to 8 days before insemination are statistically significant at $P \leqslant 0.05$; the difference 7 to 4 days before insemination is significant at $P \leqslant 0 \cdot 01$.

Table 2. Effect of plane of nutrition on plasma progesterone levels during the oestrous cycle of dairy cows

\begin{tabular}{|c|c|c|c|c|}
\hline \multirow{2}{*}{$\begin{array}{l}\text { Day of } \\
\text { cycle }\end{array}$} & \multicolumn{2}{|c|}{ High level of nutrition } & \multicolumn{2}{|c|}{ Standard level of nutrition } \\
\hline & $\begin{array}{l}\text { No.of } \\
\text { cycles }\end{array}$ & $\begin{array}{c}\text { Plasma progesterone } \\
(n g / m l)\end{array}$ & $\begin{array}{l}\text { No. of } \\
\text { cycles }\end{array}$ & $\begin{array}{c}\text { Plasma progesterone } \\
(n g / m l)\end{array}$ \\
\hline $\begin{array}{l}0 \text { to } 3 \\
4 \text { to } 7 \\
8 \text { to } 11 \\
12 \text { to } 15 \\
16 \text { to } 19 \\
20 \text { to } 23\end{array}$ & $\begin{array}{l}20 \\
20 \\
20 \\
20 \\
20 \\
15\end{array}$ & $\begin{array}{l}0.8 \pm 0.1 \\
2.0 \pm 0.2 \\
4.1 \pm 0.3 \\
5.4 \pm 0.5 \\
5.4 \pm 0.6 \\
0.7 \pm 0.1\end{array}$ & $\begin{array}{l}18 \\
18 \\
18 \\
18 \\
18 \\
15\end{array}$ & $\begin{array}{l}0.6 \pm 0.1 \\
1.6 \pm 0.3 \\
3.8 \pm 0.7 \\
4.0 \pm 0.6 \\
4.8 \pm 0.7 \\
0.9 \pm 0.1\end{array}$ \\
\hline
\end{tabular}

The results are expressed as means \pm S.E.M.

\section{Plane of nutrition and progesterone concentration}

When data from all oestrous cycles of all cows were combined, only small and non-significant differences were found in progesterone levels between cows maintained on high and standard levels of nutrition (Table 2). Likewise, among cows that conceived after the first insemination, the plane of nutrition did not 


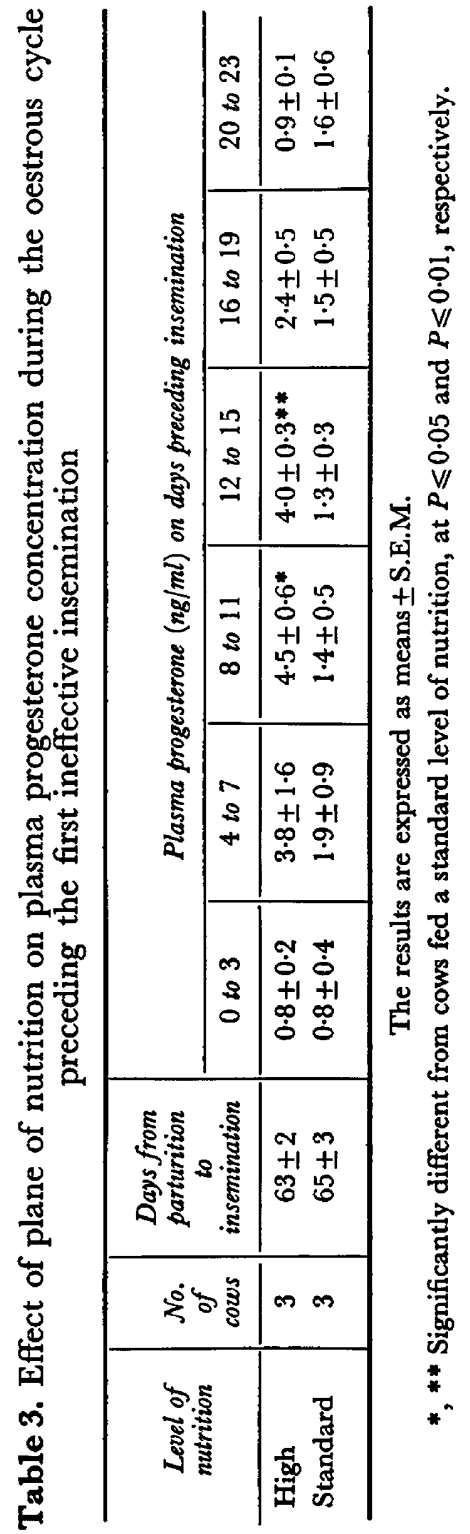


affect plasma progesterone levels during the oestrous cycle preceding insemination. On the other hand, there was a significant difference in progesterone concentration between cows maintained on the two levels of nutrition, during part of the luteal phase preceding the first ineffective insemination of cows requiring repeated insemination (Table 3 ).

Cows maintained on a high level of nutrition required fewer inseminations and conceived 19 days earlier than cows maintained on a standard level of nutrition (Table 4). First ovulation occurred at about the same time in both groups, while first oestrus was 10 days earlier in cows maintained on a high level of nutrition.

Table 4. Interval from parturition to first ovulation, first oestrus and first progesterone peak in dairy cows maintained on high and standard levels of nutrition

\begin{tabular}{|c|c|c|c|c|c|c|}
\hline \multirow{2}{*}{$\begin{array}{l}\text { Level of } \\
\text { nutrition }\end{array}$} & \multirow{2}{*}{$\begin{array}{l}\text { No. } \\
\text { of } \\
\text { cows }\end{array}$} & \multirow{2}{*}{$\begin{array}{l}\text { No. of } \\
\text { inseminations } \\
\text { required for } \\
\text { conception }\end{array}$} & \multicolumn{4}{|c|}{ Interval (days) from parturition to: } \\
\hline & & & Conception & $\begin{array}{c}\text { First } \\
\text { ovulation }\end{array}$ & $\begin{array}{c}\text { First } \\
\text { oestrus }\end{array}$ & $\begin{array}{c}\text { First progesterone } \\
\text { peak } \ddagger\end{array}$ \\
\hline High & $7 \dagger$ & $1.4 \pm 0.2$ & $78 \pm 6$ & $30 \pm 4$ & $43 \pm 6$ & $32 \pm 3^{*}$ \\
\hline Standard & 6 & $2 \cdot 2 \pm 0 \cdot 6$ & $97 \pm 18$ & $26 \pm 5$ & $53 \pm 6$ & $55 \pm 11$ \\
\hline
\end{tabular}

The results are expressed as means \pm S.E.M.

* Significantly different from cows maintained on a standard level of nutrition, $P \leqslant 0.05$.

$\dagger$ One cow kept on the high level of nutrition was excluded because she entered the experiment 4 weeks after parturition.

$\ddagger$ Plasma progesterone concentration of $5 \mathrm{ng} / \mathrm{ml}$ or more.

Cyclical changes in plasma progesterone concentrations were observed in most cows as early as the 1st month after parturition, but the level of the hormone remained low. Plasma progesterone levels seem to indicate that cows maintained on a high level of nutrition returned to post-partum reproductive activity earlier than cows maintained on a standard level of nutrition. A level of $5 \mathrm{ng} / \mathrm{ml}$ or more appeared in the cows maintained on a high level of nutrition $32 \pm 3$ days after parturition, i.e. 23 days earlier than in cows maintained on the standard level of nutrition (Table 4).

\section{Body weight and milk production}

The average body weight of all cows, recorded 3 days after parturition, was $576 \pm 14 \mathrm{~kg}$. The fluctuations in body weight were large in the 1st month after parturition and only during the 2nd month could a trend in weight changes be discerned. During this period, a loss in weight was observed in two out of eight cows that conceived after the first insemination, whereas among cows that did not conceive, four out of six lost weight. Cows that conceived after the first insemination had gained weight at the beginning of the luteal phase of the cycle preceding the insemination while cows that did not conceive had lost weight (Table 5). The correlation coefficient between changes in body weight 11 to 19 days before insemination and plasma progesterone concentrations of 


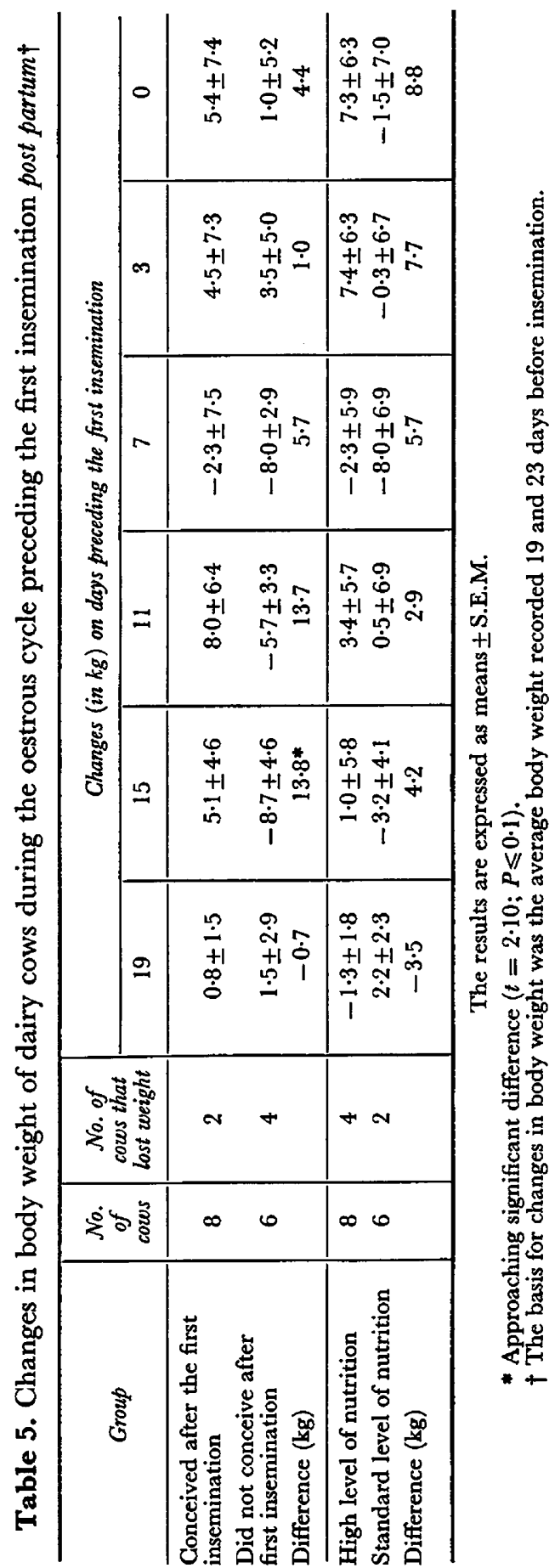


all cows on Days 8 to 15 before insemination also approached statistical significance $(r=0.492 ; P \leqslant 0 \cdot 1)$.

The average $4 \%$ fat-corrected milk yield during the 1 st, 2 nd and 3 rd months after parturition was $25 \cdot 6 \pm 1 \cdot 0,22 \cdot 7 \pm 0 \cdot 8$ and $20 \cdot 6 \pm 0 \cdot 9 \mathrm{~kg}$ per day, respectively. Only very small and statistically insignificant differences in milk production were found between nutritional treatments or between cows that did or did not conceive after the first insemination.

\section{DISGUSSION}

The plasma progesterone concentrations during the oestrous cycle found in this study are in agreement with those found by other workers in normal dairy and beef cows (Schomberg et al., 1967; Pope et al., 1969; Stabenfeldt et al., 1969; Donaldson et al., 1970; Henricks et al., 1970; Hill et al., 1970; Shemesh, Lindner $\&$ Ayalon, 1971). These workers reported average progesterone levels to be less than $1 \mathrm{ng} / \mathrm{ml}$ plasma at oestrus and 5 to $9 \mathrm{ng} / \mathrm{ml}$ at the peak of the luteal phase. These results were obtained by both the protein-binding and gas-liquid chromatography methods.

Differences in plasma progesterone concentration during the oestrous cycle preceding the first insemination, between cows that did and did not conceive, have not yet been reported. Present knowledge regarding the actions and interactions of progesterone does not provide a full explanation for this finding. Progesterone can exert its effects directly on the reproductive organs or indirectly by affecting the production or release of gonadotrophins. Progesterone has a profound effect on both the endometrium and the myometrium of the bovine (Asdell, de Alba \& Roberts, 1945, 1949) and it is possible that the post-partum uterus requires at least one progesterone-induced 'build-up' for implantation to take place. Progesterone may also reduce the pituitary content of FSH and LH (Roy, Emmerson \& Melampy, 1961) or may affect the release of LH from the pituitary (Rothchild, 1965). In the bovine, when progesterone levels decrease at the end of the luteal phase, LH levels increase (Snook et al., 1971). The large drop in plasma progesterone concentration found in cows that conceived after the first insemination may cause the release of greater quantities of gonadotrophins affecting ovulation and oestrogen production.

Contrary to the results of Erb, Randel \& Callahan (1971), who did not find any significant changes in progesterone concentration from 3 to 60 days after parturition, the results of this study indicate that progesterone levels of $5 \mathrm{ng} / \mathrm{ml}$ plasma or more were found only $32 \pm 3$ days post partum (Table 4 ). If an elevated progesterone concentration during the luteal phase is one of the criteria of normal cycling activity, then this finding is in agreement with many studies where cycling activity accompanied by behavioural oestrus began only during the 2nd month after parturition (Casida, 1971). On the basis of the present data, one can postulate that a high concentration of peripheral progesterone ( $>4 \mathrm{ng} / \mathrm{ml}$ plasma) at the peak of the luteal phase of at least one oestrous cycle before insemination is positively associated with conception. In all studies on progesterone levels in cycling cows, concentrations at the peak of the luteal phase were found to be at least $4 \mathrm{ng} / \mathrm{ml}$ plasma. Similar, or higher, levels of 
progesterone are probably a normal feature of the cycling dairy cow and unless this level is attained, the oestrous cycle lacks at least one of its components and conception does not occur during the first 90 days after parturition.

Numerous investigators have reported that plane of nutrition and changes in body weight have a profound effect on various reproductive phenomena (for reviews, see: Baker, 1969; Lamond, 1970; Wagner \& Oxenreider, 1971). A low level of nutrition generally reduces the percentage of effective inseminations and therefore prolongs the interval between parturition and conception. It has been shown that undernutrition decreases plasma progesterone concentration (Donaldson et al., 1970; Hill et al., 1970).

In the present study, nutritional treatments, although providing widely different levels of energy, did not result in any clear-cut differences in body weight. It seems plausible to assume that feeding diets with different energy levels does not in itself assure different energy balances and one can expect cows with a negative energy balance on a high plane of nutrition and vice versa. These results notwithstanding, a high proportion of cows responded to the nutritional treatments. The cows fed diets with high energy levels required fewer inseminations per conception and the interval from parturition to the first appearance of a progesterone peak was significantly shorter than in cows fed diets with low levels of energy (Table 4). The effects of nutrition may be further confounded by the possible effect of progesterone on body weight changes (Gilbert \& Gillman, 1956; Dewar, 1957; Hervey \& Hervey, 1967). The general trend in body weight changes is similar to the trend in progesterone levels. Cows that conceived after the first insemination had higher progesterone levels during the 2nd month after parturition and only $25 \%$ of them lost weight. Cows that did not conceive had lower progesterone levels and $67 \%$ of them lost weight. During the oestrous cycle preceding the first insemination, six out of eight cows that conceived gained weight while four out of the six cows that did not conceive lost weight (Table 5). Three of the latter were from the group receiving the high-energy treatment, which may suggest that changes in body weight during the cycle are associated more with reproductive phenomena than with nutrition. The difference in body weight changes preceding the first insemination, between cows that did and did not conceive, approached statistical significance despite great fluctuations in the body weight of cows. The correlation coefficient $(r=0.492)$ between plasma progesterone and body weight changes also approached statistical significance. Both suggest that an association exists between body weight changes and progesterone levels.

At the present time, it is difficult to interpret the relationship between the level of nutrition, body weight changes, plasma progesterone concentration and conception. It is suggested that these factors are interrelated in their effect on fertility and that, in the 2nd and 3rd months after parturition, plasma progesterone concentration during the oestrous cycle preceding insemination is positively related to the occurrence of conception.

\section{ACKNOWLEDGMENTS}

We are grateful to $\mathrm{Dr} \mathrm{J}$. Kali who aroused our interest in the problem of 
cattle infertility, to Dr M. Shemesh for valuable advice on the technique of protein binding and to the staff of our experimental farm at Bet Dagan for skilled technical assistance.

\section{REFERENCES}

Asdell, S. A., de Alba, J. \& Roberts, J. S. (1945) The levels of ovarian hormones required to induce heat and other reactions in the ovariectomized cow. F. Anim. Sci. 4, 277.

Asdell, S. A., De Alba, J. \& Roberts, J. S. (1949) Studies on the oestrous cycle of dairy cattle: cycle length, size of corpus luteum and endometrial changes. Cornell Vet. 39, 389.

BAKer, A. A. (1969) Post partum anoestrus in cattle. Aust. vet. 7. 45, 180.

CAsida, L. E. (1971) The post partum interval and its relation to fertility in the cow, sow and ewe. IX Biennial Symposium on Animal Reproduction. 7. Anim. Sci. 32, Suppl. 1, 66.

Dewar, A. D. (1957) The endocrine control of the extra-uterine weight gain of pregnant mice. $\mathcal{F}$. Endocr. 15, 216.

Donaldson, L. E., BassetT, J. M. \& Thorburn, G. D. (1970) Peripheral plasma progesterone concentration of cows during puberty, oestrous cycle, pregnancy and lactation, and the effects of undernutrition or exogenous oxytocin on progesterone concentration. J. Endocr. 48, 599.

Edquist, L. E., Ekman, L., Gustafsson, B. \& Aström, G. (1970) Progesterone levels in the bovine peripheral plasma measured by the competitive protein binding technique. Zentbl. VetMed. 17, 899.

ERB, R, E., Randel, R. D. \& Callahan, C. J. (1971) Female sex steroid changes during the reproductive cycle. IX Biennial Symposium on Animal Reproduction. 7. Anim. Sci. 32, Suppl. 1, 80.

Erb, R. E., Surve, A. H., Gallahan, G. J., Randel, R. D. \& Garverick, H. A. (1971) Reproductive steroids in the bovine. VII. Changes post partum. F. Anim. Sci. 33, 1060.

Garverick, H. A., Erb, R. E., Niswender, G. D. \& Callahan, G. J. (1971) Reproductive steroids in the bovine. III. Changes during the estrous cycle. F. Anim. Sci. 32, 946.

Gilbert, G. \& Gillman, J. (1956) The changing pattern of food intake and appetite during the menstrual cycle of the baboon (Papio ursinus) with consideration of some of the controlling endocrine factors. S. Afr. F. med. Sci. 21, 75.

Henricks, D. M., Dickey, J. F. \& Niswender, G. D. (1970) Serum luteinizing hormone and plasma progesterone levels during the oestrus cycle and early pregnancy in cows. Biol. Reprod. 2, 346.

Henricks, D. M., Lamond, D. R., Hill, J. R. \& Dickey, J. F. (1971) Plasma progesterone concentration before mating and in early pregnancy in the beef heifer. F. Anim. Sci. 33, 450.

Hervey, E. \& HeRvey, G. R. (1967) The effects of progesterone on body weight and composition in the rat. F. Endocr. 37, 361.

Hill, J. R., JR, Lamond, D. R., Henricks, D. M., Dickey, J. F. \& Niswender, G. D. (1970) The effects of undernutrition on ovarian function and fertility in beef heifers. Biol. Reprod. 2, 78.

LAMOND, D. R. (1970) The influence of undernutrition on reproduction in the cow. Anim. Breed. Abstr. $38,359$.

Mryake, T. (1962) Progestational substances. In: Methods in Hormone Research, Vol. II. Ed. R. I. Dorfman. Academic Press, New York and London.

Pope, G. S., Gupta, S. K. \& Munro, I. B. (1969) Progesterone levels in the systemic plasma of pregnant, cycling and ovariectomized cows. F. Reprod. Fert. 20, 369.

Randel, R. D., Garverick, H. A., Surve, A. H., Erb, R. E. \& Callahan, C. J. (1971) Reproductive steroids in the bovine. V. Comparisons of fertile and nonfertile cows 0 to 42 days after breeding. 7. Anim. Sci. 33, 104.

RoTHCHILD, I. (1965) Interrelations between progesterone and the ovary, pituitary, and central nervous system in the control of ovulation and the regulation of progesterone secretion. Vitams Horm. 23, 209.

Roy, D. E., Emmerson, M. A. \& Melampy, R. M. (1961) Effect of exogenous progesterone on reproductive activity in the beef heifer. F. Anim. Sci. 20, 373.

Schomberg, D. W., Coudert, S. P. \& ShORT, R. V. (1967) Effects of bovine luteinizing hormone and human chorionic gonadotrophin on the bovine corpus luteum in vivo. F. Reprod. Fert. 14, 277.

Shemesh, M., Ayalon, N. \& LindNer, H. R. (1968) Early effect of conceptus on plasma progesterone level in the cow. F. Reprod. Fert. 15, 161.

Shemesh, M., Lindner, H. R. \& Ayalon, N. (1971) Competitive protein-binding assay of progesterone in bovine jugular venous plasma during the oestrous cycle. F. Reprod. Fert. 26, 167.

Snook, R. B., SaAtman, R. R. \& Hansel, W. (1971) Serum progesterone and luteinizing hormone levels during the bovine estrous cycle. Endocrinology, 88, 678. 
Sprague, E. A., Hopwood, M. L., Niswender, G. D. \& Wiltbank, J. N. (1971) Progesterone and luteinizing hormone levels in peripheral blood of cycling beef cows. $\mathcal{F}$. Anim. Sci. 33, 99.

Stabenfeldt, G. H., Ewing, L. L. \& McDonald, L. E. (1969) Peripheral plasma progesterone levels during the bovine oestrous cycle. F. Reprod. Fert. 19, 433.

WAGNER, W. G. \& OXENREIDER, S. L. (1971) Endocrine physiology following parturition. IX Biennial Symposium on Animal Reproduction. F. Anim. Sci. 32, Suppl. 1, 1. 